\title{
A rare and serious cause of pancytopenia in a patient with systemic lupus erythematosus: haemophagocytic lymphohistiocytosis
}

\author{
Zakaria Almuwaqqat, ${ }^{1}$ James Wesley Roberts, ${ }^{2}$ Yazan Bashtawi ${ }^{1}$
}

${ }^{1}$ Department of Medicine, Emory School of Medicine, Atlanta, GA, USA

${ }^{2}$ Department of Pathology and Laboratory Medicine, Emory School of Medicine, Atlanta, GA, USA

\section{Correspondence to}

Dr Zakaria Almuwaqqat, zalmuwa@emory.edu

Accepted 5 September 2018

Check for updates

(c) BMJ Publishing Group Limited 2018. No commercial re-use. See rights and permissions. Published by BMJ.

To cite: Almuwaqqat $Z$, Roberts JW, Bashtawi Y. BMJ Case Rep Published Online First: [please include Day Month Year]. doi:10.1136/ bcr-2018-226758

\section{DESCRIPTION}

A 60-year-old woman with a history of hypertension, rhupus (systemic lupus erythematosus (SLE) and rheumatoid arthritis), anemia who presented to an outside hospital with generalized weakness, worsening anaemia, recurrent vomiting and had a complicated medical course including septic shock due to Escherichia coli bacteraemia with acute renal failure, acute liver injury, acute respiratory failure and pancytopenia. Patient was receiving continuous renal replacement therapy, mechanical ventilation and immunosuppression with intravenous methylprednisolone and azathioprine. Patient was weaned from mechanical ventilation and transferred to our hospital for further evaluation and treatment. Her labs were consistent with pancytopenia, positive antidouble stranded DNA, anti-SSA/RO, anti-SSB/ LA, elevated serum creatinine and elevated aspartate aminotransferase, alkaline phosphatase, reduced serum complement (C3 and C4) levels and extreme hyperferritinaemia (ferritin of 60 800) concerning for haemophagocytic lymphohistiocytosis (HLH). Further labs revealed an elevated interleukin two soluble receptor and elevated triglyceride levels. Bone marrow biopsy and aspirate were consistent with haemophagocytosis as displayed in figure 1 . Patient was started on a standard protocol of therapy that included ciclosporin, etoposide and dexamethasone. This was followed by clinical and biochemical improvement in patient's overall condition, however, the patient made the decision to transition to comfort care. HLH is known as a relatively rare complication in autoimmune diseases, particularly,

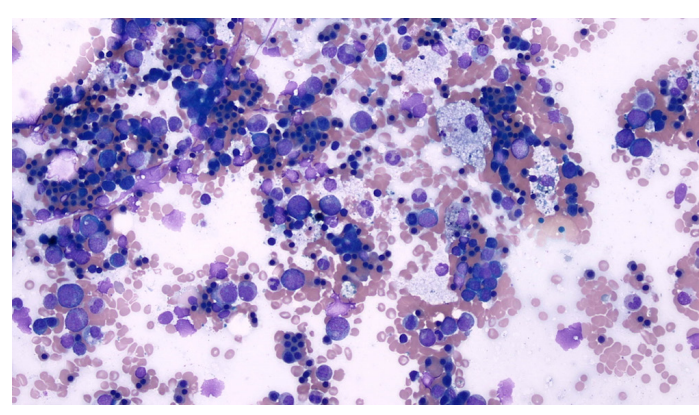

Figure 1 A bone marrow aspirate revealing phagocytosis by histiocytes of erythrocytes, leucocytes, platelets and their precursors.
SLE. ${ }^{1}$ Mortality rates may exceed $20 \%$, according to some reports. ${ }^{2}$ Older age, the presence of infection, maximum ferritin elevation and elevated CRP are associated with increased mortality. ${ }^{3-5}$ There are no validated treatment protocols, current protocols are largely based on retrospective case series and case reports. ${ }^{6}$

\section{Learning points}

- It is important to maintain a high index of suspicion for a timely diagnosis and earlier treatment.

- Bone marrow biopsy is usually diagnostic of haemophagocytic lymphohistiocytosis $(\mathrm{HLH})$, but haemophagocytosis is a late feature of $\mathrm{HLH}$.

- There are no validated treatment protocols for $\mathrm{HLH}$, current protocols are largely based on retrospective case series and case reports.

Contributors ZA: has written the case narrative. JR: has interpreted the image and provided pathological correlations.

Funding The authors have not declared a specific grant for this research from any funding agency in the public, commercial or not-for-profit sectors.

Competing interests None declared.

Patient consent Obtained.

Provenance and peer review Not commissioned; externally peer reviewed.

\section{REFERENCES}

1 Fukaya S, Yasuda S, Hashimoto T, et al. Clinical features of haemophagocytic syndrome in patients with systemic autoimmune diseases: analysis of 30 cases. Rheumatology 2008;47:1686-91.

2 Gavand PE, Serio I, Arnaud L, et al. Clinical spectrum and therapeutic management of systemic lupus erythematosus-associated macrophage activation syndrome: A study of 103 episodes in 89 adult patients. Autoimmun Rev 2017;16:743-9.

3 Allen CE, Yu X, Kozinetz CA, et al. Highly elevated ferritin levels and the diagnosis of hemophagocytic lymphohistiocytosis. Pediatr Blood Cancer 2008;50:1227-35.

4 Grangé $\mathrm{S}$, Buchonnet $\mathrm{G}$, Besnier $\mathrm{E}$, et al. The use of ferritin to identify critically ill patients with secondary hemophagocytic lymphohistiocytosis. Crit Care Med 2016;44:e1045-e1053.

5 Emmenegger U, Frey U, Reimers A, et al. Hyperferritinemia as indicator for intravenous immunoglobulin treatment in reactive macrophage activation syndromes. Am J Hematol 2001;68:4-10.

6 Henter J-I, Aricò M, Egeler RM, et al. HLH-94: a treatment protocol for hemophagocytic lymphohistiocytosis. Med Pediatr Oncol 1997;28:342-7. 
Copyright 2018 BMJ Publishing Group. All rights reserved. For permission to reuse any of this content visit http://group.bmj.com/group/rights-licensing/permissions.

BMJ Case Report Fellows may re-use this article for personal use and teaching without any further permission.

Become a Fellow of BMJ Case Reports today and you can:

- Submit as many cases as you like

- Enjoy fast sympathetic peer review and rapid publication of accepted articles

Access all the published articles

- Re-use any of the published material for personal use and teaching without further permission

For information on Institutional Fellowships contact consortiasales@bmjgroup.com

Visit casereports.bmj.com for more articles like this and to become a Fellow 